\title{
Botanical composition and some nutrient contents of the diet consumed by waterbuck (Kobus ellipsiprymnusdefassa) in Dinder National Park, Sudan
}

\author{
Tahani Ali Hassan \\ Department of Wildlife, Faculty of Natural Resources and Environmental Studies, University of Bahri, Khartoum North, \\ Sudan. Email: tahanihassanm@gmail.com. \\ Copyright (@) 2017 Hassan. This article remains permanently open access under the terms of the Creative Commons Attribution License 4.0, which \\ permits unrestricted use, distribution, and reproduction in any medium, provided the original work is properly cited.
}

Received 8th March, 2017; Accepted 25th April, 2017

\begin{abstract}
This study was conducted in the Dinder National Park (DNP) at approximately 11 to $13^{\circ} \mathrm{N}$ and long 34 to $36^{\circ} \mathrm{E}$ ) in 2015 and 2016, in order to determine the botanical composition of the waterbuck's (Kobus ellipsiprymnusdefassa) diet. The study was mainly done at Abd el Ghani Maya (meadow). A micro-histological technique was used to determine the dietary botanical composition in which samples of plant species and faecal droppings encountered in and around the Maya were collected, dried and grounded to pass 1-mm mesh. Reference slides were prepared from the ground samples of the plant species whose epidermal characteristics were compared with their counterparts in similar slides prepared from the faecal droppings. In addition, nitrogen, phosphorous and calcium concentrations in plant samples were determined. Twenty-one plant species were recorded from waterbuck faecal in 2015 and 19 in the year 2016. The grass species comprising high proportions in the diet were Echinochloa sp., Cyprus sp., kylinga sp. and Sorghum arundinaceum; forbs (broad-leaved herbs) were Corchorus depressus, Ipomoea aquatica and Polygonum sp.; and woody vegetation (trees and shrubs) were Acacia seiberiana, Balanites aegyptiaca, Ziziphusspina-christiand Crativa adonsonii. Early in the dry season, grasses and forbs constituted $80 \%$ of the diet, trees and shrubs $20 \%$. However, during the late dry season, grasses and forbs comprise about $40 \%$ of the diet; whereas trees and shrubs constituted $60 \%$. Among food plants Cyprus sp. and Acacias contained the highest nitrogen and phosphorus concentrations. The diet of waterbuck was more diverse in the late dry season than that of the early dry season. It is concluded that waterbuck preferred few succulent, nutritious grasses in the early dry season and shifts to diverse herbaceous and woody vegetation with relatively high nutrient contents when the grasses dry up late in the dry season. Nutritional studies about grasses, leguminous trees and other plant species eaten by the wild animals are lacking. Intensive nutritional studies are needed to cover all possible nutritional aspects of the wild animals in the park.
\end{abstract}

Key words: Forbs, grasses, micro-histological technique, woody trees.

\section{INTRODUCTION}

Deutsh and Murray (2001) described waterbuck (Kobus ellipsiprymnusdefassa) as the largest antelope of the Reduncini tribe, the height at shoulders on averages being 700 to $1,360 \mathrm{~mm}$ (Plate 1). Males $(250 \mathrm{~kg}$ ) are larger than females $(170 \mathrm{~kg})$. The hair is long, coarse, and usually with some shade of brown, ranging from yellow to nearly black, with white patches. The males have impressive backward-curving horns and females without horns. Ears are big and rounded. There are white patches just above the eyes, around the mouth, the nose and on the throat; the coat becomes progressively darker with age. Males tend to be darker and greyer than females. All waterbucks have a large, white patch on their rump (Estes 1991).

Plant cover and plant diversity, an important component of wildlife habitat, provides waterbuck, like other wildlife herbivores, with food and shelter. Knowledge of the plants eaten by the waterbuck (feeding habit or diet selection) is vital for the proper management of its habitat. In the African savanna ecosystems, the 


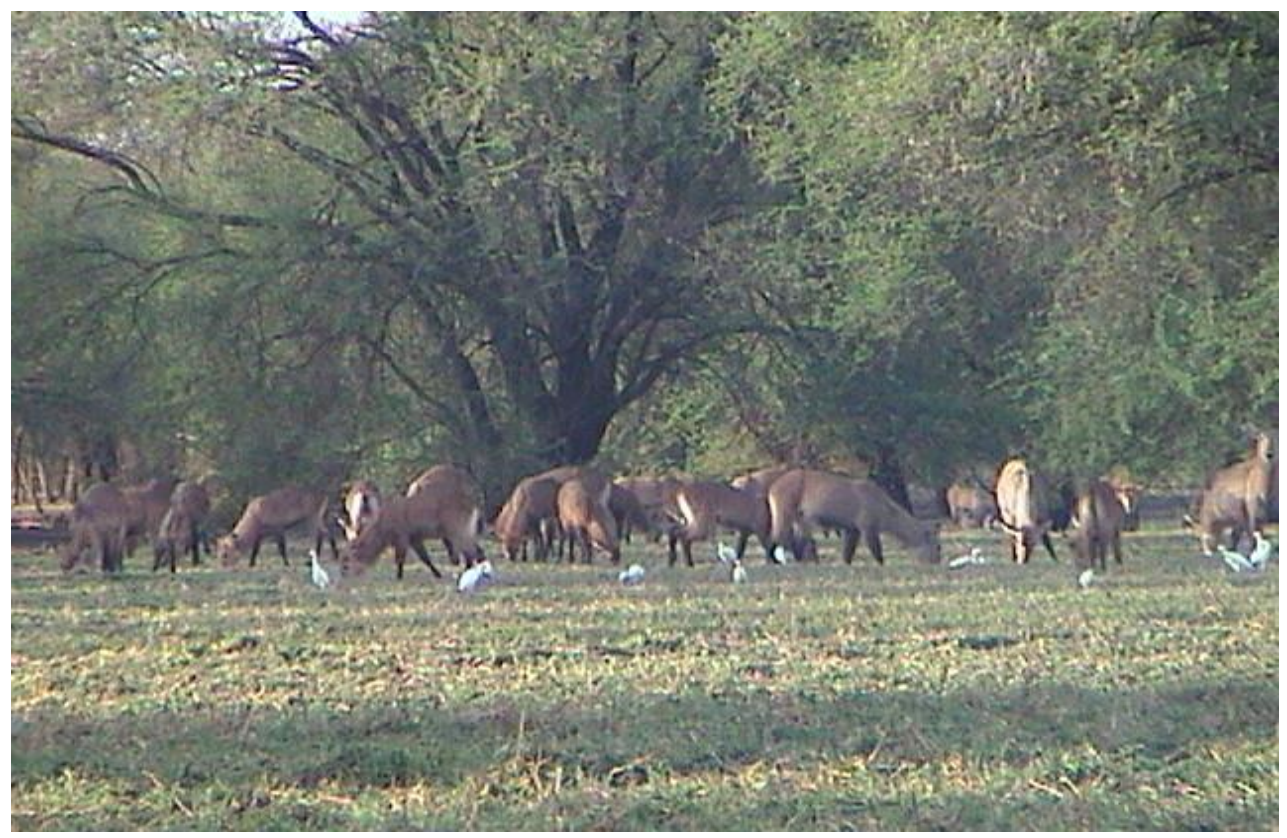

Plate 1. Waterbuck (Kobus ellipsiprymnusdefassa) grazing in Abdel Ghani Maya, Dinder National Park, Sudan.

mortality is either induced by food shortage or by a significant decrease in food quality can even exceed the deaths of wild animals caused by the various predators (Sinclair 1977).

The diet of herbivorous ungulates varies between seasons and nutrient levels vary among plant species with the seasonal advance: as the plants become mature and their nutrient contents decrease (Mowat et al. 1965; Georgiadis and McNaughton 1990). It is suggested that plant species with comparatively low nutrient levels in the wet season might become relatively of high quality and hence more attractive for herbivores later than in the dry season when other herbaceous plants dry out (Mowat et al. 1965; Prins and Beekman 1989; Georgiadis and McNaughton 1990; Ben-Shahar and Coe 1992). This explains why the diet botanical composition of ungulates varies between seasons in many studies (Prins and Beekman 1989; Ego et al. 2003; Macandza 2004; Omphile et al. 2004). Literally, the quality and availability of food plants are constraints to the population dynamics of ungulates (Sinclair 1977; Boyce 1992; Mwangi and Western 1998).

Epidermal characteristics of plant species recovered in fragmentary conditions from faeces were widely applied for studying herbivorous diets (Dussi 1949). The main purpose of applying this technique to free-ranging wild animals is the identification of forage plants after being ingested by the animal. The identification of epidermal fragments in feces was proven to be successful, especially in areas where several animal species were feeding together on rich herbaceous flora such as that of
East African plains (Stewart 1967). Waterbuck, as noticed by East (1984), feeds selectively but on less widely dispersed forage parts as compared to other ungulates. It moves from one habitat to the next habitat, searching for high quality food (Traill 2004).

Considerable research is being conducted on feeding preference and fluctuations in nutritive values of food plants of domestic livestock. However similar studies on wild herbivorous ungulates are scarce. In addition, most information on plant-herbivore interactions in savanna ecosystems was obtained in moist savannahs which may be different from semi-arid regions. The main objective of this study was to determine the botanical composition, and nitrogen, phosphorus and calcium contents as well as the seasonal shift in the diet consumed by the waterbuck in Dinder National Park during the dry season of 2015 and 2016.

\section{MATERIALS AND METHODS}

\section{The study area}

This study was conducted in the Dinder National Park (DNP), which is located in the Sennar State between latitudes 11 to $13^{\circ} \mathrm{N}$ and longitudes 34 to $36^{\circ} \mathrm{E}$, adjacent to the Ethiopian border at a distance of $550 \mathrm{~km}$ south east of Khartoum. It is drained by two seasonal rivers, Dinder and Rahad, and the area covers $10,290 \mathrm{~km}^{2}$. The climatic conditions of park in general, can be summarized as cool and dry in winter and wet and warm in summer. The wet season starts in May and ends in November, 
during which the area receives an annual rain fall ranging 600 to $1000 \mathrm{~mm}$, increasing southwards and peaking in August. The temperature range from as low as $20^{\circ} \mathrm{C}$ at the begging of the dry season in December to as high as $42^{\circ} \mathrm{C}$ in March and April, towards the end of the dry season. Rahad and Dinder Rivers start flooding in July, reaching their peak in September. The annual mean relative humidity varies between $35 \%$ and $45 \%$ but higher value of $79 \%$ was recorded during the peak of the rains in August (Kanno 2004). The dry season extends from December to April, with maximum temperature of $38^{\circ} \mathrm{C}$ in April, the winter is cool with mean average temperature of $30^{\circ} \mathrm{C}$ (Kanno 2004).

\section{Data and sample collection}

The samplings used follow the method of Hashim (1987, 1996). The faecal pellets of the waterbuck were counted in circular plots of $1 \mathrm{~m}$ radius, along randomly selected four lines transects that radiated from the center of the Maya and ended beyond its periphery to a distance of 1 $\mathrm{km}$. Plots were spaced at $50 \mathrm{~m}$ intervals where faecal pellet-groups were collected for micro-histological analysis; each pellet group was kept separately in a paper bag and sun dried. In total, 1850 pellet samples, representing 10 to 50 pellets/groups were collected. There were no errors in identifying the faecal pelletgroups because their shapes and sizes were species specific. No distinction was made between the animal sexes, but juvenile' faeces were excluded from the analyses.

Plant species were counted in the plots along the same line transects used for the sampling of the faecal pelletgroups. Grasses, forbs and branches of tree species in the plots were clipped for chemical analysis. Each plant species was kept separately in a paper bag and dried in the sun. Ripe, fallen seed pods of the leguminous trees encountered during the sampling were also collected and kept for the laboratory analysis.

The micro-histological analysis was used to determine the dietary composition of the waterbuck (Stewart 1967). It is based on the fact that, fragments of epidermis and cuticles of plants ingested by animals remain intact as they pass through the digestive system and could be identified in the dung. Based on the shape and distribution of epidermal cell forms, the plant fragments found in the dung can be identified up to the species or genus level. Accordingly, reference slides were prepared from leaves of all grass, forbs and tree species available in the DNP as well as seed pods of the leguminous trees, according to Essas (1963).

\section{Nutrient analysis}

Nitrogen was determined by the Kjeldahl digestion (Bradstreet 1965). Plant materials were ground and incubated at $420^{\circ} \mathrm{C}$ for one hour with $5 \mathrm{ml}$ of concentrated sulphuric acid $\left(\mathrm{H}_{2} \mathrm{SO}_{4}\right)$ and a Kjeldahl tablet. The digested solution was then transferred into a $100 \mathrm{ml}$ Erlenmeyer flask and filled up with distilled water. This solution was neutralized and the total nitrogen concentrations were measured by means of the Flow Injection Analysis. Crude protein content was calculated as 6.25 times the nitrogen concentration, as proteins on average consist of $16 \%$ nitrogen (Robbins 1993). Phosphorus, ash and calcium were determined according to Van Soest (1975) and then $\mathrm{Ca} / \mathrm{P}$ ratio of each sample was calculated.

Microsoft excel computer program was used to analyze the seasonal shift in the diet of waterbuck as well as nitrogen, phosphorus, and calcium concentrations.

\section{RESULTS}

\section{Diet composition}

The diets' botanical composition of waterbuck in the early and late dry seasons of 2015 and 2016 are shown in Table 1 and Table 2. Among the 21 plant species recovered in the early dry season (Table 1), $49.3 \%$ were grasses, $22.4 \%$ forbs and $28.3 \%$ trees. Seven grass species dominated the diet composition; their proportions range from 9.0 to $5.9 \%$. These plants, in the order of their high proportion, were Echinochloa sp., Cyprus sp., Kylinga sp., Sorghum arundinaceum and Pennise tumsp. The proportion of forbs (22.4\%) did not differ very much as they range from 2.3 to $4.8 \%$. The woody vegetation, however, comprised $28.3 \%$ of the diet. Setaria sp. and Setaria verticillata (grasses), and the three tree species (Balanites aegyptiaca, Ziziphus-spina-christi and Crativa adonsonii) were not recovered.

Plant species indicating recovered high diet proportion ( 7.3 to $5.1 \%$ ) late in the dry season comprised $40.8 \%$ trees (Acacia nilotica, Acacia seiberiana, Acacia seyal, Acacia fistula and Crativa adonsonii), and $27.6 \%$ grasses (Setaria verticillata and Setaria sp.) and $15 \%$ forbs (Astercantha longifolia, Polygonum sp. and Hibiscus pando niformis). Although they were avoided in the early dry season, Setaria verticillata, Balanites aegyptiaca and Ziziphus-spina-christi were consumed late in the dry season.

In 2016, 19 plant species were recovered during the early dry season (Table 2 ). Among these, 10 species had high proportions (11.4 to $5.3 \%$ ) in the diet. These constituted $70 \%$ grasses (Cyprus gigantia, Echinochloa sp., Kylinga sp., Sorghum arundinaceum, Cyprus imbricatus, Hyparhernia rufa and Pennise tumsp.); $20 \%$ forbs (Ipomoea equatica and Asparagus sp.), and 10\% trees (Acacia seiberiana). In the late dry season proportion of the 22 plant species that were selected ranged from 8.5 to $1.4 \%$. The species with relatively high proportions (8.5\% to $5.0 \%$ ) were $58 \%$ trees (Acacia 
Table 1. Diet botanical composition of waterbuck (Kobus ellipsiprymnusdefassa) in the early and late dry season of 2015 at Dinder National Park.

\begin{tabular}{|c|c|c|}
\hline \multirow{2}{*}{ Plant species } & \multicolumn{2}{|c|}{ Percentage } \\
\hline & Early dry season & Late dry season \\
\hline \multicolumn{3}{|l|}{ Grasses } \\
\hline Cyprus gigantia & 8.3 & 5.2 \\
\hline Cyprus imbricatus & 7.4 & 4.1 \\
\hline Kylingasp. & 6.1 & 4.4 \\
\hline Echinochloasp. & 9.0 & 2.1 \\
\hline Echinochloasp. & 8.0 & 4.8 \\
\hline Pennisetumsp. & 4.6 & 1.9 \\
\hline Setariasp. & 0 & 2.3 \\
\hline Setariaverticillata & 0 & 6.0 \\
\hline arundinaceum & 5.9 & 3.3 \\
\hline Total & 49.3 & 34.1 \\
\hline \multicolumn{3}{|l|}{ Forbs } \\
\hline Asparagus sp. & 4.8 & 1.3 \\
\hline Hibiscus pandoniformis & 3.3 & 5.3 \\
\hline Ipomoea equatica & 2.7 & 1.4 \\
\hline Corchorusdepressus & 3.2 & 2.2 \\
\hline Helolropiumsupinum & 3.1 & 2.6 \\
\hline Polygonumsp. & 3.0 & 5.1 \\
\hline Astercanthalongifolia & 2.3 & 7.2 \\
\hline Total & 22.4 & 25.1 \\
\hline \multicolumn{3}{|l|}{ Woody trees } \\
\hline Acacia seibriana & 5.9 & 7.2 \\
\hline Acacia polycantha & 3.6 & 4.6 \\
\hline Acacia fistula & 3.6 & 6.6 \\
\hline Acacia nilotica & 5.3 & 7.3 \\
\hline Acacia seyal & 2.4 & 7.0 \\
\hline Combretumhartmannianum & 1.7 & 3.5 \\
\hline Leptadiniasp. & 1.8 & 3.7 \\
\hline Balanitesaegyptiaca & 0 & 0.2 \\
\hline Ziziphus-spina- Christi & 0 & 0.2 \\
\hline Crativaadonsonii & 0 & 0.3 \\
\hline Unidentified items & 4 & 0.2 \\
\hline Total & 28.3 & 40.8 \\
\hline
\end{tabular}

nilotica, Acacia seiberiana, Acacia seyal, Combretum hartmannianum, Ziziphus-spina-christi and Acacia fistula); 21\% grasses (Sorghum arundinaceum, Echinochloasp., Cyprus gigantia and Setarias p.), and $21 \%$ forbs (Ipomoea equatica and Asparagus sp). Among the grass species, only Setaria sp. was not recovered in the early dry season. Kyliga sp., Hyparherina rufa and pennesetum sp. were not recovered in the late dry season although their proportion in the diet early in the dry season was $91.6 \%$. Obviously, the diet of waterbuck shifted from herbs (grasses and forbs) in the early dry season to trees and shrubs in the late dry season (Figure 1).

\section{Nutrient content}

Crude protein, phosphorous and calcium concentrations 
Table 2. Diet botanical composition of waterbuck (Kobus ellipsiprymnusdefassa) in the early and late dry season of 2016 at Dinder National Park, Sudan.

\begin{tabular}{|c|c|c|}
\hline \multirow{2}{*}{ Plant species } & \multicolumn{2}{|c|}{ Percentage } \\
\hline & Early dry season & Late dry season \\
\hline \multicolumn{3}{|l|}{ Grasses } \\
\hline Cyprus gigantia & 11.4 & 6.3 \\
\hline Cyprus imbricatus & 6.8 & 2.3 \\
\hline Kylingasp & 8.7 & 0 \\
\hline Hyparrheniarufa & 5.6 & 0 \\
\hline Pennisetumsp. & 5.3 & 0 \\
\hline Echinochloasp. & 9.1 & 6.4 \\
\hline Setariasp. & 0.0 & 5.5 \\
\hline Sorghum arundinaceum & 7.2 & 7.1 \\
\hline Total & 54.1 & 27.6 \\
\hline \multicolumn{3}{|l|}{ Forbs } \\
\hline Ipomoea equatica & 5.9 & 2.0 \\
\hline Hibiscus pandoniformis & 0.7 & 2.0 \\
\hline Asparagus sp & 6.9 & 0 \\
\hline Heliotropiumsupinum & 4.0 & 3.2 \\
\hline Astercanthalongifolia & 3.9 & 5.0 \\
\hline Polygonumsp & 3.6 & 3.3 \\
\hline Total & 25.0 & 15 \\
\hline \multicolumn{3}{|l|}{ Woody trees } \\
\hline Acacia sieberiana & 6.7 & 8.2 \\
\hline Acacia polycantha & 2.2 & 4.4 \\
\hline Acacia fistula & 0 & 5.2 \\
\hline Acacia nilotica & 4.3 & 8.5 \\
\hline Acacia seyal & 2.7 & 6.5 \\
\hline Combretumhartmannianum & 0 & 5.6 \\
\hline Leptadiniasp & 1.4 & 5.9 \\
\hline Balanitesaegyptiaca & 0 & 1.7 \\
\hline Ziziphu-sspina-christi & 0 & 5.4 \\
\hline Crativaadonsonii & 0 & 2.4 \\
\hline Acacia melifera & 0 & 1.4 \\
\hline Entadasudanica & 3.1 & 1.7 \\
\hline Unidentified items & 0.5 & 0 \\
\hline Total & 20.9 & 56.9 \\
\hline
\end{tabular}

varied between seasons. In the early dry season, the crude protein concentration in trees/shrubs and grasses was slightly more than that in forbs. The same trend was indicated in the late dry season, but the concentration in trees/shrubs was almost equal to that of the early dry season (Figure 2). Concerning the plants recovered from waterbuck faecal in the early dry season, the phosphorous concentration was relatively high in trees/shrubs compared to grasses and forbs, the grasses indicated slightly more concentration than forbs. The same trend was followed in the late dry season, but the phosphorous concentration was higher in the recovered plants in this season compared with their counterparts in the early dry season (Figure 3 ).

The calcium concentration indicated quite a different trend, being equal in grasses and forbs in the early dry season, but it was slightly higher in trees/shrubs. However, in the late dry season, however, the calcium concentration was higher in grasses compared to that of forbs, and in tress/shrubs, even exceeded the concentra- 


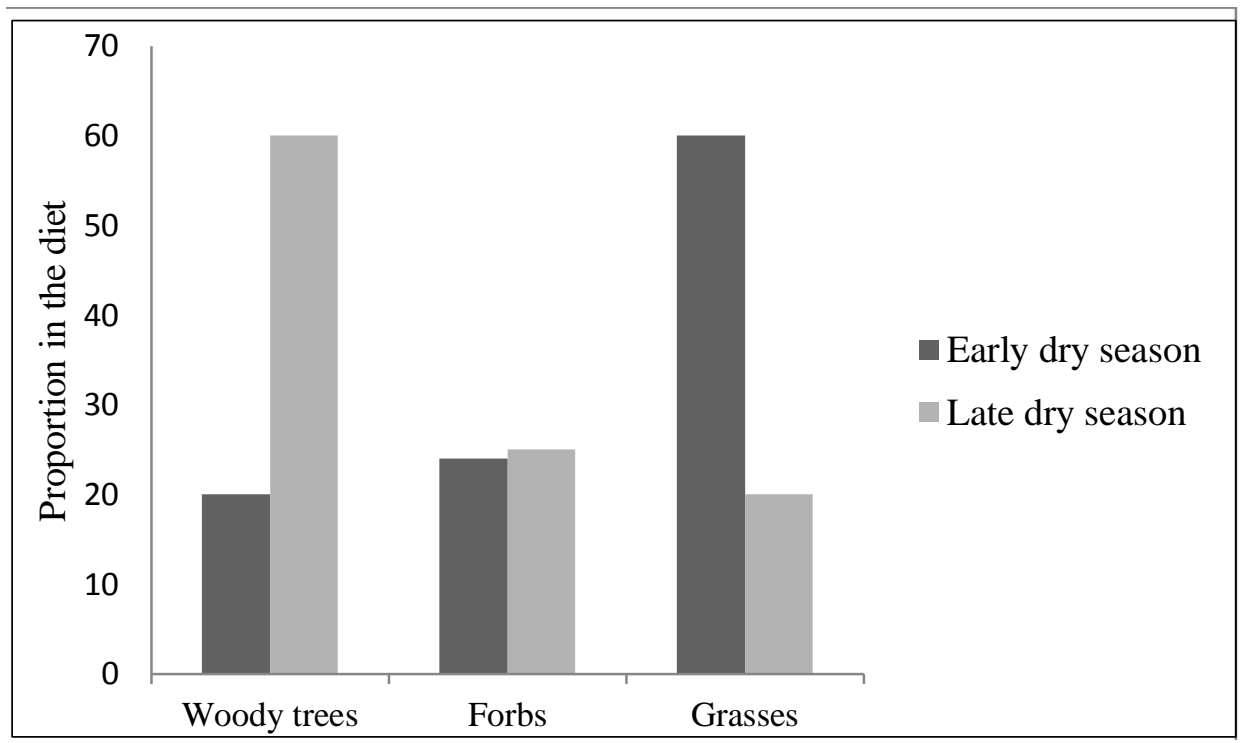

Figure 1. Average seasonal shift in proportion of dietary plant of waterbuck (Kobus ellipsiprymnusdefassa) in the early and late dry season of 2015 and 2016 at Dinder National Park, Sudan.

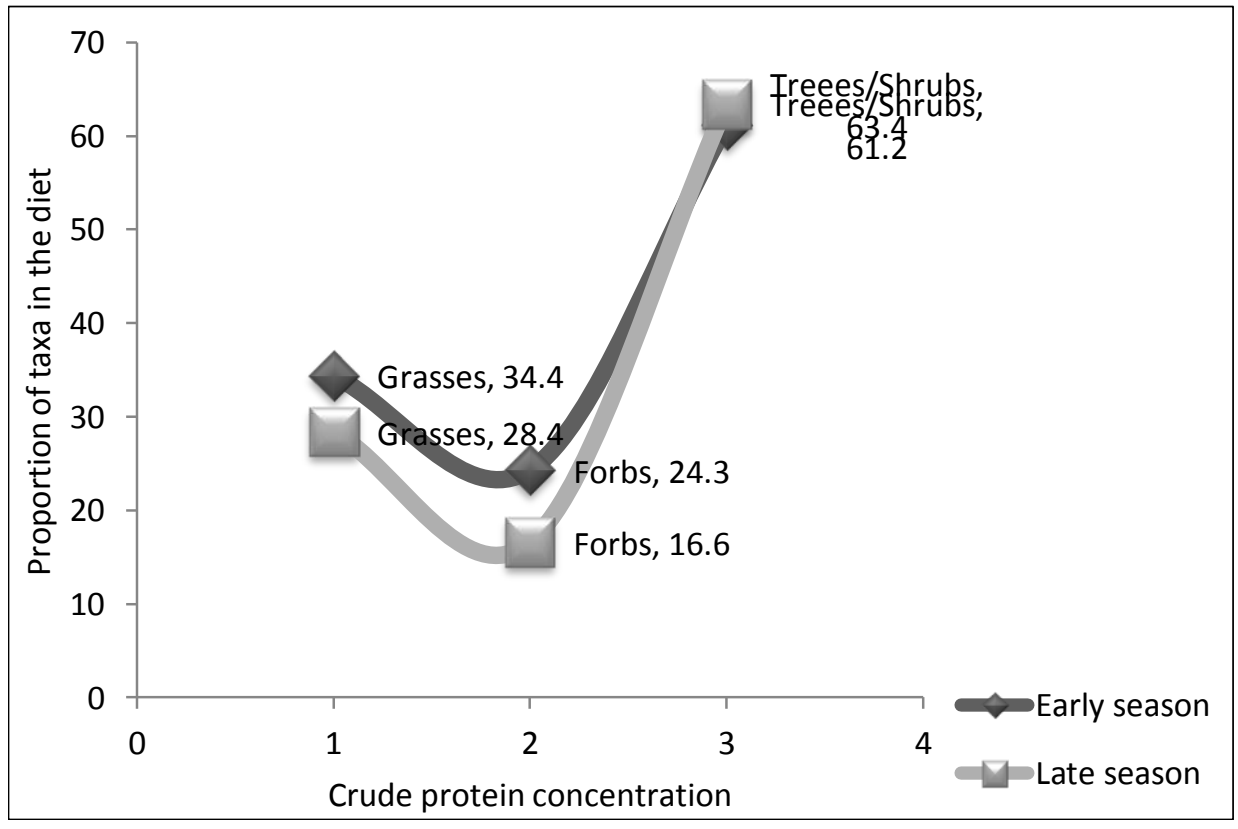

Figure 2. Crude protein concentration in taxarecovered from waterbuck(Kobus ellipsiprymnusdefassa)faecal material with seasonal advance in Dinder National Park, Sudan.

tion in the early dry season (Figure 4).

\section{DISCUSSION}

Waterbuck has consistently selected almost similar food items in early and late dry seasons of both 2015 and 2016 years. In the early dry season the diet is mostly composed of grasses, followed by forbs and trees/shrubs. In the late dry season, the tress/shrubs dominate the diet, followed by grasses and forbs. Similar findings were previously reported by Muya (1993). 


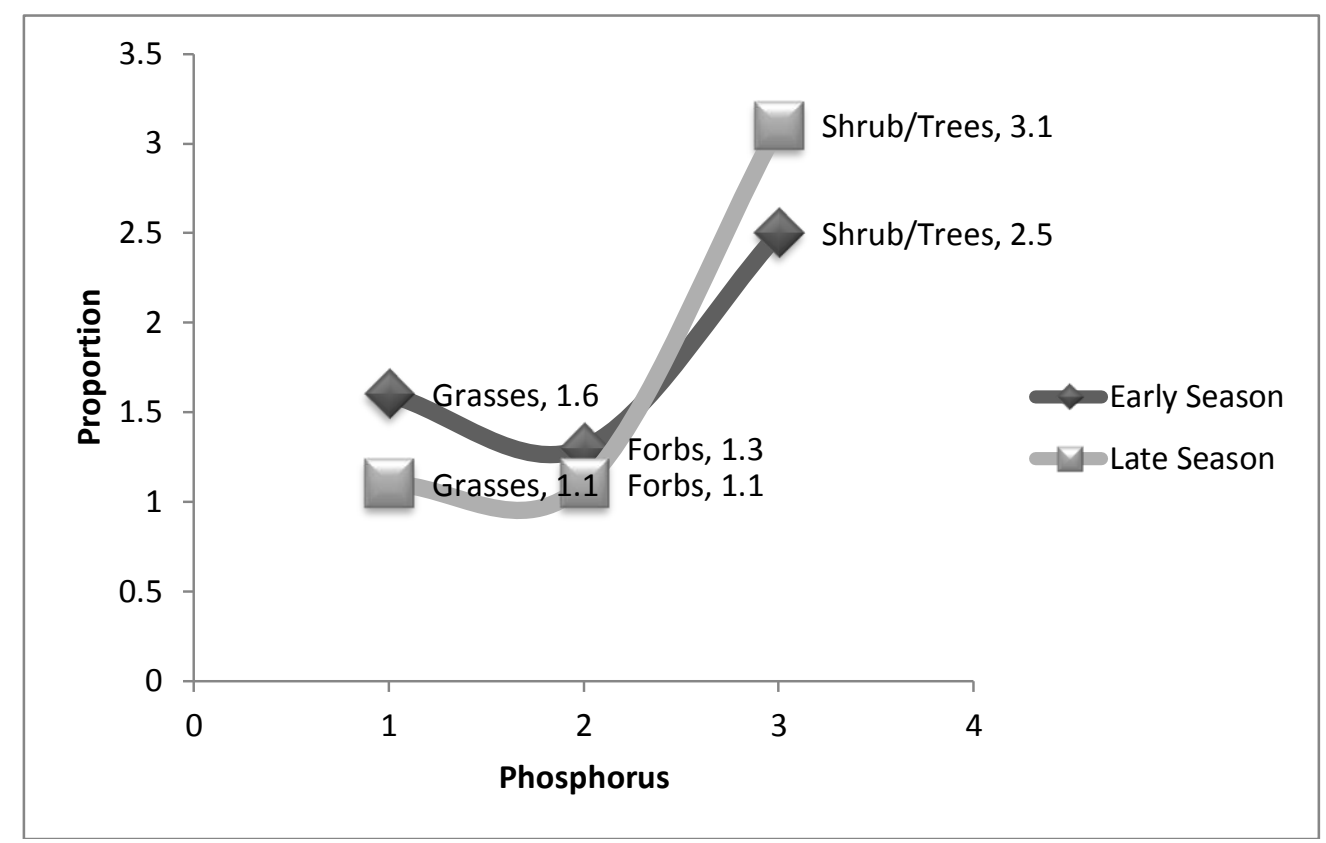

Figure 3. Phosphorus contents of taxarecovered from waterbuck faecal material with seasonal advance inDinder National Park, Sudan.

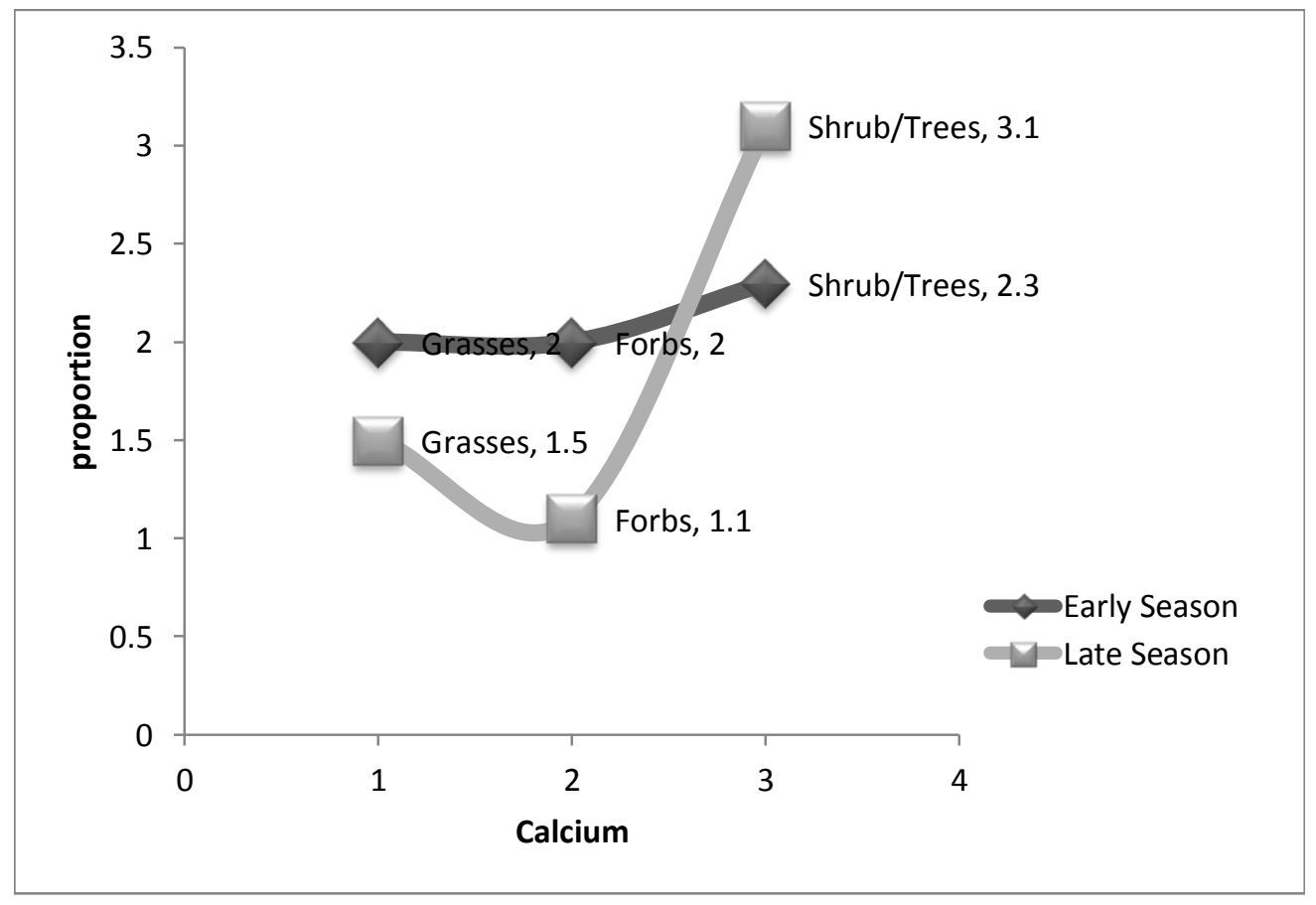

Figure 4. Calcium concentration in taxa recovered from waterbuck faecal material with seasonal advance in Dinder National Park, Sudan.

However there is a discrepancy concerning availability of plants that are not recovered: Setaria sp., Balanites aegyptiaca, Ziziphus-spina-christi and Crativa adonsonii were not consumed in the early dry season in the first year but were consumed in the late dry season. In the second year Setaria sp. Was not consumed again but 
Kyliga sp., Hyparherina rufa and pennesetum sp. were eaten in the early dry season. These have not appeared in the diet in the late dry season. Apparently, Seraria sp. is unpalatable. Taking the first year as an example, taxa refused in the early dry season might be consumed in the late dry season as they were absent in the diet. It is likely that Kyliga sp., Hyparherina rufa and pennesetum sp. were over consumed early in the dry season so that they were no longer available late in the dry season. Elhassan (2011) investigated that 2011 was a drought year and food was not probably adequately available in the area.

The crude protein, phosphorous and calcium concentrations are consistently higher in trees/shrubs compared to grasses and forbs, and the concentrations of these nutrients vary slightly between grasses and forbs. Apparently, the consumed herbs indicate more nutrient concentrations than the refused. The phosphorous concentration is more in the consumed herbs than those that were refused by the waterbuck. The waterbuck shifts its herb-dominated diet in the early dry season to tree/shrub-dominated diet in the late dry season so as to obtain these much needed nutrients at such critical time of the year. Taxa that were selected in both seasons have relatively high nutrient concentrations. Sinclair (1977) found that buffalo (Syncerus caffer) and wildebeest (Connochae testaurinus) in Serengeti National Park in Tanzania experienced severe food shortage and sharp reduction in protein and phosphorous concentration in the dry season. Previous investigators, Sinclair (1977) and Ego et al. (2003) reported that the diet of waterbuck was made up of plant species with more proportions of nutrient concentrations compared to the plant species that were not eaten.

In conclusion, waterbuck prefers few succulent, nutritious grasses in early dry season and shifts to diverse herbaceous and woody vegetation with relatively high nutrient contents when the grasses dry up in the late dry season.

\section{Recommendation}

i. Control of the wild fires that might burn fallen seed pods of Acacias that were preferred by waterbuck late in the dry season.

ii. Mayas are critical sites that contain water and green fodder for the waterbuck and other herbivores. It is imperative to improve them and increase this water holding capacity.

iii. Observationtal and nutritional studies must be conducted during the rainy season in the park to know the seasonal variation in the activities, diet composition and national requirements.

\section{CONFLICT OF INTEREST}

The authors declare that there is no conflict of interest.

\section{REFERENCES}

Ben-Shahar, R., \& Coe, M. J. (1992). The relationships between soil factors, grass nutrients and the foraging behavior of Wildebeest and Zebra. Oecologica 90, 422-428.

Boyce, M. S. (1992). Wolf recovery for Yellowstone National Park: a simulation model. In: Wildlife 2001. D. R. McCultlough and R. A. Barrett (Eds). Elsevier Science Publishers, London.

Bradstreet, R.B. (1965). The Kjeldahl Method for Organic Nitrogen. Academic Press, New York.

Deutsch, J., \& Murray, M. (2001). Grazing antelopes. The encyclopedia of mammals. Macdonald, New York.

Dussi, J. L. (1949). Methods for the determination of food habits by plant microtechniques and histology and their application to cottontail rabbit food habits. Journal of Wildlife Management, 13, 295-298.

Dunham, k. M. (1994). The effect of drought on the large mammal populations of Zambezi riverine. woodlands. Journal of Zoology (London), 234, 489-526.

Elhassan, E. F. (2011). Seasonal Abundance and Diversity of Waterbirds at Eleven Mayas in Dinder National Park, Sudan.M.Sc. thesis,.Sudan Academy of Science. Khartoum, Sudan.

East, R. (1984). Rainfall, soil nutrient status and biomass of large African savanna mammals. African Journal of Ecology, 22, 245-270.

Ego, W. K., Mbuvi, D. M., \& Kibet, P. F. K. (2003). Dietary composition of wildebeest (Connochaetestaurinus) kongoni (Alcephalusbuselaphus) and cattle (Bosindicus) grazing on a common ranch in south-central Kenya. African Journal of Ecology, 41, 83-92.

Essas, J. A. (1963). Micro-botanical Techniques. Aloe University press. $3^{\text {rd }}$ edition

Estes R. D. (1991). The Behavior Guide to African Mammals, including Hoofed Mammals, Carnivores and Primate. The University of California Press. Davis, California

Georgiadis, N. J., \& McNaughton, S. J. (1990). Elemental and fibre contents of savanna grasses: variation with grazing, soil type, season and species. The Journal of Applied Ecology, 27(2), 623-634.

Hashim, I. M. (1987). Relationship between biomass of forage used and masses of faecal pellets of wild animals in meadows of the Dinder National Park. African Journal of Ecology, 25, 217-223.

Hashim, I. M. (1996). Faecal pellets and biomass of some wild herbivores in Dinder National Park, Sudan. African Journal of Ecology, 34, 66-69.

Kanno, I. O. (2004). Application of Remote Sensing in Monitoring Ecological Changes in Dinder National Park, $P h D$ Thesis, University of Juba, Khartoum, Sudan.

Macandza, V. A. (2004). Forage selection by African buffalo in the late dry season in two landscapes. South African Journal of Wildlife Research, 34(2), 113-121.

Mowat, D. N., Fulkerson, R. S., Tossell, W. E., \& Winch, J. E. (1965). The in vitro digestibility and protein content of leaf and stem proportions of forages. Canadian Journal of Plant Science, 45, 321-331.

Muya, S. M. (1993). Nairobi National Park Black Rhino Food Plant. Rhino Conservation Programme, wildlife service, Nairobi. Unpublished Technical Report.

Mwangi, E. M., \& Western, D. (1998). Fluctuations in food supply in an insularise and heavily grazed savannah ecosystem in Kenya. African Journal Ecology, 36, 207-212. 
Omphile, U. J., Aganga, A. A., Tshireletso, K., \& Nkele, R. (2004). Foraging strategies of sheep and goats under semiintensive management in Botswana. South African Journal of Animal Science, 34 120-122.

Prins, H. H. T., \& Beekman, H. (1989). A balanced diet as a goal for grazing: the food of the Manyara buffalo. African Journal of Ecology, 27, 241-259.

Robbins, S. P. (1993). Functional interaction of large herbivores on grasslands. (Ed. French, N. R.), Colorado State University, Fort Collins. Colorado.

Sinclair, A. R. E. (1977). The resource limitation of trophic levels in tropical grassland Ecosystems. Journal of Animal Ecology, 44(2), 497-520.
Stewart, D. R. M. (1967). Analysis of plant epidermis in feces: a technique for studying the food preferences of grazing herbivores. Journal of Applied Ecology, 4(1), 83-111.

Traill, L.W. (2004). Seasonal utilization of habitat by large grazing herbivores in semi-arid Zimbabwe.South African Journal of Wildlife Research 34(1), 13-24.

Van Soest, P. J. (1975). Allometry and Ecology of Feeding Behavior and Digestive Capacity in Herbivores: A Review. Zoo Biology, 15, 455-479. 